Received : 2019-06-23 Revised : 2019-06-26 Acceptance : 2019-06-27 Publish : 2019-07-22

\title{
THE RELATION BETWEEN NURSES AGE AND COMPLIANCE IN THE IMPLEMENTATION OF PREVENTION OF FALLING PATIENTS IN THE GENERAL HOSPITAL OF THE SAMARINDA GOVERNMENT
}

\author{
M. Bachtiar Safrudin ${ }^{1}$, Milkhatun ${ }^{2}$ \\ ${ }^{1}$ Department of Nursing, Faculty of Health and Pharmacy, Universitas Muhammadiyah \\ Kalimantan Timur \\ ${ }^{2}$ Department of Nursing, Faculty of Health and Pharmacy, Universitas Muhammadiyah \\ Kalimantan Timur
}

Corresponding Author :mbs143@umkt.ac.id

\begin{abstract}
In the patient safety standards / International Patient Safety Goal (IPSG), especially the prevention of the risk of falling must be applied by nurses, age is one of the internal factors that affect compliance. This study aims to determine the correlation between age of nurses with adherence in the implementation of prevention of falling patients in Samarinda Government Hospital using a descriptive correlation design and cross sectional approach. The instrument used in this study was a questionnaire and observation sheet with a sample of 51 nurses in the non-intensive inpatient room with a purposive sampling technique. The analysis test in this study uses the Spearman rank test with the results of $p$ value 0.026 (rho $=0.312$ ), so it can be concluded that there is a significant influence between the age of nurses with adherence in the implementation of prevention of falling patients.
\end{abstract}

Keywords: age, compliance, prevention of falling patients

\section{INTRODUCTION}

In recent decades, patient safety has become a priority for all health professionals in hospitals, because providing patient safety services is an important part of improving hospital quality. Reducing the risk of patients injured due to falls is one part of patient safety goals, if the risk of patients injured due to falls can be reduced, the healing process in patients will be faster. Patient safety in hospitals is a global and national issue, according to Law No. 44 / 2009, 1 hospital as a means of health services aimed at improving the degree of public health better.

Hospitals that obtain an international accreditation, must apply the conditions set for patient safety namely, Six Goal Patient Safety (Six Goal Patient Safety) which is also used by the PERSI Hospital Patient Safety Committee (KKPRS) and the Joint Commission International (JTI) ${ }^{1}$. There are 2 argues that nurses are one of the service providers who are at risk of making mistakes in patient safety because most of the patient safety standards / International Patient Safety Goal (IPSG) are applied by nurses, especially in the implementation of preventing falling patients. The majority of health workers in hospitals are nurses (40-60\%), who have the 
mandatory duty to always prevent falling patients, so nurses have an important role in determining the success of hospital accreditation.

In a study conducted data on reports of incidents of patients falling, as many as 250,000 people experience falls every year in British and Weles hospitals, 30-50\% of which cause physical injuries $1-3 \%$ cause fractures $^{2}$. There are 34 XII PERSI congress reports were obtained during the year 2012 totaling 34 incidents or equivalent to $14 \%$ of incidents falling in hospitals in Indonesia ${ }^{3}$. This is evidence that the incidence of injured patients due to falls is still high and far from the accreditation standard which states that it is expected to not occur in hospitals or $0 \%$ of incidents.In an effort to support patient safety, nurse compliance is required in the implementation of nursing care. Age is one of the internal factors that influence one's compliance ${ }^{4}$.

The results of interviews conducted on October 19, 2018 with the Head of Nursing and Head of the Emergency Room at one of the Samarinda General Government Regional Hospitals, it was found that based on reported incident report data, of the 40 incidents recorded from July to October 2018, there were 2 incident cases of patients falling in the inpatient room. From the results of a preliminary study conducted to 10 nurses through the interview process in one of the inpatient rooms of the Samarinda Government Hospital, it was found that all nurses had good knowledge about preventing the risk of falling in patients, namely by installing a safety fence on the patient's bed and by giving a sign fall risk in patients at high risk of falling. However, at the time of observation in the room, of the 29 patients there were 11 patients who did not do the Morse Fall Scale assessment, 4 patients with a high risk of falling were not given a sign of fall risk, 2 patients with a high risk of falling in their beds were not lowered and 25 patients bed safety fence is not installed, if the condition continues to be left then it is likely that the incident of a patient falling in the hospital will re-occur.

\section{MATERIAL AND METHOD}

The study design used a quantitative descriptive cross-sectional design with 129 nurse populations in Samarinda Government Hospital. The sample in this study amounted to 51 nurses who served in the inpatient room had a minimum Diploma III in Nursing and nurses who were willing to become respondents with the purposive sampling technique. The data was taken using a questionnaire of self data and an Observation Sheet regarding the implementation of prevention of falling patients as well as the Morse Fall Scale assessment to measure nurses' compliance in the implementation of prevention of falling patients that had been carried out by expert tests.

The study was conducted after the researcher received a study permit and exclusion after the respondent signed the informed consent. The data management process consists of editing, coding, data entry, tabulating, and cleaning. Analysis of the study used the Spearman rank test Univariat.

\section{RESULT AND DISCUSSION}


Tabel 1.

Age Frequency of Nurses

\begin{tabular}{lcc}
\hline \multicolumn{1}{c}{ Ages of Responden } & Total & Presentage (\%) \\
\hline $17-25$ Y.O & 7 & 13,7 \\
$26-35$ Y.O & 34 & 66,7 \\
$36-45$ Y.O & 10 & 19,6 \\
\hline Jumlah & 51 & 100 \\
\hline
\end{tabular}

Sumber : Data Primer 2019

Based on the results of the study, it is obtained that the majority age of the respondents involved in the study in the age range of 26-35 years or early adulthood, as many as 34 respondents $(66.7 \%)$

Tabel 2.

Nurse Compliance Frequency in the Implementation of Prevention of Fall Patients

\begin{tabular}{lcc}
\hline \multicolumn{1}{c}{ Compliance } & Total & Presentage (\%) \\
\hline & & \\
Compliance & 36 & 70,6 \\
Non-complianve & 15 & 29,4 \\
\hline Jumlah & 51 & 100
\end{tabular}

Sumber : Data Primer 2019

Based on the results of the study, the majority of obedient nurses obtained obedience, as many as 36 respondents $(70.6 \%)$, while those who did not comply were 15 respondents $(29.4 \%)$.

\section{Univariat}

Age

Based on the research results, it is known that the most respondents are in the age range of 25-35 years as many as $34(66.7 \%)$ respondents, of which $26(51.0 \%)$ are compliant and $8(15.7 \%)$ are not compliant. It is known that the value of $p=0.026(<0.05)$, there is a significant relation between the age of nurses with adherence in the implementation of prevention of falling patients. The results in table 3 show $p=0.026$, meaning that there is a significant relation between the age of nurses and adherence. Correlation value of 0.312 which shows a positive correlation with low correlation strength.

Based on the research results, it is known that the most respondents are in the age range of 25-35 years as many as $34(66.7 \%)$ respondents, of which $26(51.0 \%)$ are compliant and $8(15.7 \%)$ are not compliant. It is known that the value of $\mathrm{p}=0.026(<0.05)$, there is a significant relation between the age of nurses with adherence in the implementation of prevention of falling patients. The results in table 3 show $\mathrm{p}=0.026$, meaning that there is a significant relation between the age of nurses and adherence. Correlation value of 0.312 which shows a positive correlation with low correlation strength.

\section{Nurse Compliance in the Implementation of Prevention of Fall Patients}


Based on the results in table 2, a description of nurses' compliance in the implementation of prevention of falling patients in Samarinda Government Hospital was mostly compliant, with 36 respondents $(70.6 \%)$, while those who did not comply were 15 respondents $(29.4 \%)$. From this it can be concluded that the overall number of respondents who obey more than those who do not. This is in line with research conducted which shows that most respondents comply with SPO: reducing the risk of injury due to falls ${ }^{5}$.

Five compliance is a human behavior of the size of the storage of the implementation of services compared with predetermined service standards ${ }^{4}$. Non-compliance as a serious medical problem and can be fatal ${ }^{6}$. The degree of non-compliance varies according to the class of treatment. Is the treatment curative or preventive, long term or short term. Compliance can be defined as a determination through a concrete activity or form of a person's response to an order, a suggestion. Factors such as education, environment, and social, knowledge, age and family support will affect someone in obeying something around him ${ }^{6}$.

Based on this, the researcher assumes that the behavior, characteristics and attitudes of a person which are reflected in their daily attitudes in accepting something will have an effect on someone's compliance or non-compliance in carrying out the rules that apply around them. So that when a nurse is accustomed to ignoring adherence to an action, then the nurse will get used to ignoring it. Therefore the researcher gives a suggestion that fellow nurses can remind each other when they miss an action procedure that should be done and it is their responsibility to improve patient safety.

\section{Bivariate}

\section{The Relation Between Nurse Age and Obedience in the Implementation of Fall Patient Prevention}

The results in table 3 show $\mathrm{p}=0.026$, meaning that there is a significant relation between the age of nurses and adherence. Correlation value of 0.312 which shows a positive correlation with low correlation strength. The majority of respondents in this study were in early adulthood. So it can be concluded that the distribution of nurses with productive age is still large.

In line with research conducted which states that age is one of the factors that influence a person in carrying out an action ${ }^{7}$. The study, showed that there was a significant relation between age and nurse compliance, with a $\mathrm{p}$ value of 0.003 (>0.05). A person's knowledge can affect one's persistence in carrying out a procedure of action, the more age a person eats his knowledge will also increase.

Based on this, the researcher assumes that the age of the nurse can describe the behavior of the patient in implementing a procedure. The majority of respondents in the range of early adulthood, where they are considered to be able to circulate thoroughly and more easily receive information and obey in carrying out an action. It is recommended that younger and senior nurses need to receive patient safety training, especially in the prevention of falls in each 
inpatient unit. In addition, it is important for senior nurses of relatively older age to provide guidance to younger nurses in preventative measures for falling patients.

\section{CONCLUSION}

Based on the results of the study it can be concluded that the compliance of nurses in the implementation of prevention of falling patients in Samarinda City Government Hospital is influenced by the age level of nurses.

\section{For nurses}

It is hoped that nurses can carry out tasks that are already the responsibility of nurses in their profession, namely by carrying out patient prevention measures in accordance with existing procedures. It is also expected that nurses can increase knowledge about patient safety, especially in the prevention of falling patients with training organized by Samarinda Government Hospital and fostering good communication between fellow nurses and with superiors, so that it affects the implementation of tasks in hospitals, especially in the implementation of prevention of falling patients .

2. For the management of Samarinda Government Hospital.

It is expected to increase the knowledge of nurses in inpatient installations about patient safety, especially in the prevention of falling patients by holding periodic training and orienting new nurses about patient safety. As well as conducting routine supervision of the performance of nurses in order to make nurses to be more compliant with existing regulations and improve the quality of hospital services.

\section{For educational institutions}

The results of this study are expected to be a source of information for educational institutions in teaching or explaining the importance of the implementation of prevention of falling patients in accordance with standard procedures. As well as an input field in the learning process activities in research programs relating to nurse compliance in the implementation of prevention of falling patients.

\section{For further researchers}

Future researchers are expected to be able to carry out continuous research using independent variables and different methods and it is hoped that further researchers will add theories and references to perfect previous research.

\section{REFERENCES}


1. Maulidiawati, Ita. Nursalam. Endang Nihayati, Hanik. Development Of A Supervision Model Besed On Experiential Learning For The Implementation Of Patient Safety Goals At A Teaching Hospital In Surabaya. 2018. Jurnal Ners, 12.2 (2017)

2. Morris, Rob. O'Riordan, Shelagh. Prevention Of Falls In Hospital.Journal Clinical Medicin 2017. 17.4 (2017)

3. Ainin, Hirza., Dharmana, E., \& Santoso, A., Pelaksanaan Asesmen Risiko Jatuh di Rumah Sakit. Jurnal Ners dan Kebidanan Indonesia, 5, 2. (2017).

4. Notoatmodjo, S. Promosi Kesehatan Dan Ilmu Perilaku. Jakarta: Rineka Cipta. (2010)

5. Susanti, Ranti. Hubungan Pengetahuan Dengan Kepatuhan Perawat Melaksanakan Standar Prosedur Opersional: Menurunkan Risiko Cidera Akibat Jatuh Di Ruang Perawatan Dewasa RSUD Dr. Moewardi. Stikes Kusuma Husada Surakarta.( 2015)

6. Niven, N. Psikologi Kesehatan Edisi 2. Jakarta: EGC. (2002)

7. Ratnasari, Dahlia. Faktor-Faktor Yang Berhubungan Dengan Kepatuhan Perawat Ruang Rawat Inap Dalam Pelaksanaan Hand Hygiene Di Rumah Sakit Anna Medika Kota Bekasi Tahun 2016. Jurnal Ilmiah Kesehatan.8.2.(2016) 